\title{
Oxidation of the enzymes involved in nitrogen assimilation plays an important role in the cadmium-induced toxicity in soybean plants
}

\author{
K. B. Balestrasse · S. M. Gallego · M. L. Tomaro
}

Received: 17 January 2006/ Accepted: 27 February 2006

(C) Springer Science+Business Media B.V. 2006

\begin{abstract}
Cadmium causes oxidative damage and hence affects nitrogen assimilation. In the present work we tested the relationship between the inactivation of the enzymes involved in nitrogen assimilation pathway (glutamine synthetase (GS)/glutamate synthase (GOGAT)) and the protein oxidation in nodules of soybean (Glycine $\max$ L.) plants under $\mathrm{Cd}^{2+}$ stress. Therefore, the effect of $\mathrm{Cd}^{2+}$ and reduced gluthatione (GSH) on GS and GOGAT activities, and protein abundance and oxidation were analyzed. Under the metal treatment, amino acids oxidative modification occurred, evidenced by the accumulation of carbonylated proteins, especially those of high molecular weight. When $\mathrm{Cd}^{2+}$ was present in the nutrient solution, although a decrease in GS and GOGAT activities was observed (17 and 52\%, respectively, compared to controls), the protein abundance of both enzymes remained similar to control nodules. When GSH was added together with $\mathrm{Cd}^{2+}$ in the nutrient medium, it protected the nodule against $\mathrm{Cd}^{2+}$ induced oxidative damage, maintaining GS and GOGAT activities close to control values. These results allow us to conclude that the
\end{abstract}

Section Editor: H. Schat

K. B. Balestrasse · S. M. Gallego · M. L. Tomaro $(\bowtie)$ Departamento de Química Biológica, Facultad de Farmacia y Bioquímica, Universidad de Buenos Aires, Junín 956, 1113 Buenos Aires, Argentina

e-mail: ptomaro@ffyb.uba.ar inactivation of the nitrogen assimilation pathway by $\mathrm{Cd}^{2+}$ in soybean nodules is due to an increment in GS and GOGAT oxidation that can be prevented by the soluble antioxidant GSH.

Keywords Bradyrhizobium japonicum .

Cadmium · Glycine $\max$ L. · Nitrogen assimilation · Protein oxidation
Abbreviations
DAB-3, $3^{\prime}$
diaminobenzidine
2,4-DNPH-2,4 dinitrophenylhydrazine
GOGAT
glutamate synthase (EC 1.4.1.14)
GS
ROS glutamine synthetase (EC 6.3.1.2)
TBS reactive oxygen species Tris-buffered saline
TTBS Tris-buffered saline plus Tween

\section{Introduction}

The symbiotic association of leguminous plants with (Brady)rhizobium results in the formation of root nodules, which are able to reduce $\mathrm{N}_{2}$ to $\mathrm{NH}_{4}^{+}$by the enzyme nitrogenase (EC 1.18.6.1). Ammonium is rapidly assimilated by glutamine synthetase (GS, EC 6.3.1.2), which catalyses the ATP-dependent amination of glutamate, producing glutamine (Lea and Miflin 2004). Glutamine is subsequently deaminated 
by the enzyme glutamate synthase (GOGAT, EC 1.4.1.14) that catalyses the reductive transfer of the amido group of glutamine to the $\alpha$-keto position of 2 oxoglutarate, yielding two molecules of glutamate (Lancien et al. 2000).

Cadmium is a potent poison for all living cells. Several studies suggest that oxidative stress is involved in $\mathrm{Cd}^{2+}$ toxicity, by either inducing oxygen free radical production, or by decreasing enzymatic and non-enzymatic antioxidants (Benavides et al. 2005). Oxidative stress is a condition referred to as an imbalance between oxidant generation and antioxidant systems. As a consequence of this phenomenon, an enhanced amount of cellular oxidation products is formed (compared to physiological levels). Reactive oxygen species (ROS) generated as by-products of cellular metabolism or from environmental sources cause modifications to the amino acids of proteins (Nyström 2005). Oxidatively modified proteins can undergo chemical fragmentation or form aggregates because of covalent cross-linking reactions and increase surface hydrophobicity, leading to a loss of function (Berlett and Stadtman 1997).

Reduced glutathione (GSH), a reductant molecule that protects thiol groups of enzymes and react with singlet oxygen $\left({ }^{1} \mathrm{O}_{2}\right)$, hydrogen peroxide $\left(\mathrm{H}_{2} \mathrm{O}_{2}\right)$ and the hydroxyl radical $(\mathrm{OH})$, plays a pivotal role in protecting the plants from ROS injury (Gratäo et al. 2005). Not only elevated levels of GSH are correlated with environmental stress tolerance, but also enhanced GSH synthesis seems to be an intrinsic response of plants to stress (May et al. 1998). Adaptation to grow in the presence of $\mathrm{Cd}^{2+}$ was linked to the capacity to maintain high intracellular GSH concentration (Gallego et al. 2005).

The effect of different $\mathrm{Cd}^{2+}$ concentrations on soybean nodule metabolism has been extensively studied in our laboratory (Balestrasse et al. 2001, 2003, 2004, 2005). Cadmium causes oxidative damage and hence affects nitrogen fixation and assimilation in roots and nodules of soybean plants. More detailed studies of $\mathrm{Cd}^{2+}$ effect on soybean nodules should be necessary in order to understand the mechanisms of metal toxicity. In the present work, we study the relationship between the GS/GOGAT pathway inactivation and protein oxidation in soybean nodules subjected to $\mathrm{Cd}^{2+}$ stress condition. The protective effect of the soluble antioxidant GSH was also analyzed.

\section{Materials and methods}

Plant material and growing conditions

Seeds of soybean (Glycine max L. cv. AG 445-RG, Nidera) were surface sterilized with $5 \% \mathrm{v} / \mathrm{v}$ sodium hypochlorite solution $\left(25 \mathrm{~g} \mathrm{l}^{-1}\right.$ available chlorine) for $10 \mathrm{~min}$ and washed several times with distilled water. Seeds were inoculated with $10^{8}$ cell ml ${ }^{-1}$ of Bradyrhizobium japonicum (109, INTA Castelar) and planted in vermiculite. After germination at 5 day, plants were removed from pots, roots were gently washed and transferred to separate containers for hydroponics. Plants were germinated and grown in a controlled climate room at $24 \pm ; 2^{\circ} \mathrm{C}$ and $50 \%$ relative humidity, with a photoperiod of $16 \mathrm{~h}$ and a light intensity of $175 \mu \mathrm{mol} \mathrm{m} \mathrm{m}^{-2} \mathrm{~s}^{-1}$. The hydroponic medium was nitrogen-free Hoagland nutrient solution containing $1.5 \mathrm{mM} \quad \mathrm{KH}_{2} \mathrm{PO}_{4}, \quad 0.8 \mathrm{mM}$ $\mathrm{MgSO}_{4} \cdot 7 \mathrm{H}_{2} \mathrm{O}, 2.5 \mathrm{mM} \mathrm{KCl}, 0.8 \mathrm{mM} \mathrm{CaCl}{ }_{2} \cdot 2 \mathrm{H}_{2} \mathrm{O}$, $5 \mathrm{mM} \quad \mathrm{Fe}$-EDTA, $\quad 1 \mu \mathrm{M} \quad \mathrm{MnSO}_{4} \cdot \mathrm{H}_{2} \mathrm{O}, \quad 1 \mu \mathrm{M}$ $\mathrm{ZnSO}_{4} \cdot 7 \mathrm{H}_{2} \mathrm{O}, 12.5 \mu \mathrm{M} \mathrm{H}_{3} \mathrm{BO}_{3}, 0.25 \mu \mathrm{M} \mathrm{H}_{2} \mathrm{MoO}_{4}$ and $0.25 \mu \mathrm{M} \mathrm{CuSO}_{4} \cdot 2 \mathrm{H}_{2} \mathrm{O}$ (pH 5.8) (Hoagland and Arnon 1957). Medium was continuously aerated, and replaced every 3 days. After 4 weeks, plants were treated with nutrient solution devoid of $\mathrm{Cd}^{2+}$ and GSH (control), or containing $200 \mu \mathrm{M} \mathrm{CdCl}_{2}, 200 \mu \mathrm{M}$ $\mathrm{CdCl}_{2}$ plus $300 \mu \mathrm{M}$ GSH or $300 \mu \mathrm{M} \mathrm{GSH}$. After $48 \mathrm{~h}$ of treatment nodules were isolated and used for determinations. Each experiment was repeated three times and consisted of five replicates $(n=15)$.

\section{Determination of $\mathrm{Cd}$ content}

Nodule tissues without and with $\mathrm{Cd}^{2+}$ addition, and with $\mathrm{Cd}^{2+}$ plus $\mathrm{GSH}$ were thoroughly rinsed four times with distilled water containing $10 \mathrm{mM}$ Na-EDTA to eliminate the metal that could be superficially adsorbed. Plant material was dried at $80^{\circ} \mathrm{C}$ during $48 \mathrm{~h}$, weighed and ground to a fine powder. Cadmium determinations were made on $\mathrm{HNO}_{3}: \mathrm{HClO}_{4}(3: 1 \mathrm{v} / \mathrm{v})$ digests by atomic absorption spectrophotometry (Perkin-Elmer, AAnalyst 300).

Enzyme determinations

Plant material $(0.3 \mathrm{~g})$ for GS determination was extracted in $50 \mathrm{mM}$ Tris- $\mathrm{HCl}$ buffer ( $\mathrm{pH} 7.5$ ) containing $1 \mathrm{mM}$ 2-mercaptoethanol and $2 \mathrm{mM}$ EDTA, 
and homogenized at $4^{\circ} \mathrm{C}$. Following centrifugation $(15,000 \times g)$ for $30 \mathrm{~min}$ at $4^{\circ} \mathrm{C}$, GS activity was measured in an assay buffer consisting of $50 \mathrm{mM}$ Tris- $\mathrm{HCl}$ (pH 7.5), $4 \mathrm{mM}$ ATP, $80 \mathrm{mM} \mathrm{Na-gluta-}$

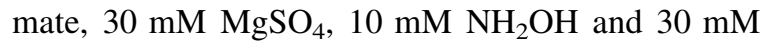
cysteine (Kanamori and Matsumoto 1972). A standard curve was made using $\gamma$-glutamyl hydroxamate.

Extracts for determination of GOGAT activity were prepared from $0.3 \mathrm{~g}$ of nodules homogenized in $3 \mathrm{ml}$ of extraction buffer containing $100 \mathrm{mM}$ MES$\mathrm{NaOH}$ buffer (pH 6.8), $100 \mathrm{mM}$ sucrose, $2 \%$ (v/v) 2mercaptoethanol, and $15 \%(\mathrm{v} / \mathrm{v})$ ethyleneglycol at $4^{\circ} \mathrm{C}$. Homogenates were centrifuged at $10,000 \times g$ for $20 \mathrm{~min}\left(4^{\circ} \mathrm{C}\right)$ and the supernatant fraction was used for the assays. GOGAT was determined in the homogenates by measuring the decrease in absorption at $340 \mathrm{~nm}$ due to NADH oxidation, in a reaction medium containing $100 \mathrm{mM}$ potassium phosphate buffer (pH 7.6), $0.1 \%$ (v/v) 2-mercaptoethanol, $100 \mu \mathrm{M}$ $\mathrm{NADH}, 2.5 \mathrm{mM}$ 2-oxoglutarate and $100 \mathrm{mM}$ glutamine (Groat and Vance 1981).

\section{Western-blot analysis for GS and GOGAT}

Proteins from nodules were subjected to denaturing sodium dodecyl sulfate polyacrylamide gel electrophoresis (SDS-PAGE) in a Mini-PROTEAN 3 System (Bio-Rad Laboratories, Hercules, CA, USA). SDS-PAGE was performed in 7.5 and $12 \%$ gels $(4 \%$ stacking gels), for GOGAT and GS respectively, and run according to Laemmli (1970). The separated polypeptides were transferred to a nitrocellulose membrane at $250 \mathrm{~mA}$ constant for $2 \mathrm{~h}$ in a Mini-Trans-Blot Electrophoretic System (Bio-Rad) according to the manufacturer's instructions. The membranes were washed in $25 \mathrm{mM}$ Tris- $\mathrm{HCl}$ (pH 8.5), $192 \mathrm{mM}$ glycine and 20\% (v/v) methanol. The blots were blocked by incubation for $2 \mathrm{~h}$ in $2 \%(\mathrm{w} / \mathrm{v})$ powdered non-fat dry milk dissolved in Tris-buffered saline (TTBS), (20 mM Tris- $\mathrm{HCl} \mathrm{pH} 7.6,137 \mathrm{mM}$ $\mathrm{NaCl}, 0.1 \%$ (v/v) Tween 20) before reaction with the appropriate antibody. The membrane was incubated with rabbit antibody against barley leaf NADHGOGAT for GOGAT (dilution 1:1000), or rabbit antibody against GS purified from $P$. vulgaris root nodules (Cullimore and Miflin 1984) for GS (dilution 1:1000). Dilution of antibodies was in TTBS with $2 \%$ (w/v) powdered non-fat dry milk for NADH-GOGAT and GS. The blots were washed two times for $10 \mathrm{~min}$ each with TTBS. Goat anti-rabbit horseradish peroxidase conjugate was used as secondary antibody. The blots were washed two times for $10 \mathrm{~min}$ before color development (ECL immunodetection system, ECL Western Blotting protocols, Dako).

Carbonyl groups determination

Protein oxidation was measured as total carbonyl groups content by reaction with 2,4-dinitrophenylhydrazine (2,4-DNPH) (Levine et al. 1990). Extracts $(50 \mu \mathrm{g}$ of protein) derivatized with 2,4 DNPH were separated by SDS-PAGE in $12 \%(\mathrm{w} / \mathrm{v})$ running and $4 \%(\mathrm{w} / \mathrm{v})$ stacking polyacrylamide gels (Laemmli 1970). Two gels were run simultaneously: one for protein staining with Coomassie Brilliant Blue R-250 and the other for immunodetection. Derivatized proteins were transferred onto nitrocellulose membranes and were detected with rabbit antiDNP primary antibody from Sigma-Aldrich (St Luis, USA). Bands corresponding to oxidized proteins were visualized by secondary goat anti-rabbit immunoglobulins conjugated with horseradish peroxidase and using 3,3'-diaminobenzidine (DAB) as a substrate.

Immunoprecipitation and immunochemical detection of GS and GOGAT carbonyl groups

Proteins $(100 \mu \mathrm{g})$ derivatized with DNPH as mentioned above, were separated by affinity chromatography. Antibodies anti-DNP $(50 \mu \mathrm{l})$ were linked to cyanogen bromide activated sepharose $4 \%$ agarose matrix (100 mg) from Sigma-Aldrich (St Luis, USA). Samples were incubated overnight at $4^{\circ} \mathrm{C}$ with excess of anti-DNP-agarose resin and then centrifuged for $5 \mathrm{~min}$ at $10,000 \times \mathrm{g}$ and at $4^{\circ} \mathrm{C}$. Resin beads were washed 3 times with Tris-buffered saline (TBS), pellets were re-suspended in $50 \mu \mathrm{l}$ of $100 \mathrm{mM}$ glycine ( $\mathrm{pH}$ 2.5). After centrifugation, pellets were discarded, the $\mathrm{pH}$ of the supernatants was adjusted to 6.8 and used for immunodetection of GS and GOGAT. DNPH derivatized proteins were separated by $12.5 \%$ $(w / v)$ SDS-PAGE. After electrotransfer of the proteins to nitrocellulose membranes, GS and GOGAT were detected as described above. In all cases, membranes were photographed with a Fotodyn equipment, and the intensity of bands was analyzed 
with GelPro software and expressed as arbitrary units based on absolute integrated optical density.

Protein determination

Protein concentration was determined according to Bradford (1976) using bovine serum albumin as a standard.

Statistical analysis

Values indicate mean values \pm s.e. Differences among treatments were analyzed by one-way ANOVA, taking $P<0.05$ as significant according to Tukey's multiple range test.

\section{Results}

Nodule cadmium concentrations

Since $\mathrm{Cd}^{2+}$ and GSH were added to the nutrient solution together, there could be a likelihood that $\mathrm{GSH}$ and $\mathrm{Cd}^{2+}$ interact outside the plant decreasing $\mathrm{Cd}^{2+}$ bioavailability for uptake. In order to verify this possibility, nodule $\mathrm{Cd}$ concentrations were determined. As shown in Table 1, the presence of GSH did not affect the cadmium uptake, and the levels of $\mathrm{Cd}^{2+}$ were similar to those found when the plants were treated only with $200 \mu \mathrm{M}$ of the metal ion.

Effect of cadmium on the nitrogen assimilation pathway

The behavior of the enzymes involved in the nitrogen assimilation (GS and GOGAT) in soybean plant nodules was studied. In plants subjected to $200 \mu \mathrm{M}$

Table 1 Cadmium concentrations in soybean nodules

\begin{tabular}{lc}
\hline Treatments & Cd concentration $\mu \mathrm{g} / \mathrm{g} \mathrm{DW}$ \\
\hline Control & $6.52 \pm 0.52$ \\
$\mathrm{Cd}^{2+}$ & $80.31 \pm 0.52^{*}$ \\
$\mathrm{Cd}^{2+}+\mathrm{GSH}$ & $78.20 \pm 0.52^{*}$ \\
$\mathrm{GSH}$ & $5.52 \pm 0.43$ \\
\hline
\end{tabular}

Nodule tissues were used for the assays. Experiments were carried out as described in Materials and methods. Data are the means \pm S.E.M. of three different experiments with five replicated measurements. *Significant differences $P<0.05$ according to Tukey's multiple range test
$\mathrm{Cd}^{2+}$ during $48 \mathrm{~h}$, GS and GOGAT activities significantly decreased (17 and 52\%, respectively, compared to controls). When the nutrient solution was supplemented with $300 \mu \mathrm{M}$ GSH (with and without $\mathrm{Cd}^{2+}$ ), the enzyme activities remained similar to the controls (Table 2).

To test whether modification of the GS and GOGAT activities in nodules induced by $\mathrm{Cd}^{2+}$ treatment were due to protein abundance modification, SDSPAGE and Western blots were performed. No significant differences were observed either in GS or in GOGAT protein content in nodules subjected to $\mathrm{Cd}^{2+}$ treatment (Figs. 1, 2). Similarly, no effect with GSH addition was observed.

Effect of cadmium on soluble proteins and carbonyl groups content

The effect of $\mathrm{Cd}^{2+}$ on soybean nodule proteins and their carbonyl groups content was evaluated. Soybean plants were treated with $200 \mu \mathrm{M} \mathrm{Cd}^{2+}, 200 \mu \mathrm{M} \mathrm{Cd}^{2+}$ plus $300 \mu \mathrm{M}$ GSH or $300 \mu \mathrm{M}$ GSH for $48 \mathrm{~h}$. Although $\mathrm{Cd}^{2+}$ treatment altered total soluble protein content in the nodule (data not shown), the extracts had similar soluble protein profile in SDS-PAGE staining with Coomassie Blue (Fig. 3).

In nodules, $\mathrm{Cd}^{2+}$ treatment significantly increased carbonyl groups content (34\% compared to control plants). This enhancement was totally prevented when GSH was included in the nutrient solution (Fig. 4a). When immunodetection of carbonyl

Table 2 Effect of cadmium and GSH treatments on ammonium assimilation enzyme activities

\begin{tabular}{lll}
\hline Treatment & GS (U/mg protein) & GOGAT $(\mathrm{U} / \mathrm{mg}$ protein) \\
\hline Control & $0.757 \pm 0.019$ & $0.046 \pm 0.002$ \\
$\mathrm{Cd}^{2+}$ & $0.638 \pm 0.027 * *$ & $0.022 \pm 0.002^{*}$ \\
$\mathrm{Cd}^{2+}+\mathrm{GSH}$ & $0.776 \pm 0.005$ & $0.055 \pm 0.007$ \\
$\mathrm{GSH}$ & $0.736 \pm 0.015$ & $0.054 \pm 0.006$ \\
\hline
\end{tabular}

Soybean (Glycine max L.) nodulated plants were treated with nutrient solution devoid of cadmium and glutathione (control) or containing $200 \mu \mathrm{M} \mathrm{Cl}_{2} \mathrm{Cd}, 300 \mu \mathrm{M} \mathrm{GSH}$ or $200 \mu \mathrm{M} \mathrm{Cl}_{2} \mathrm{Cd}$ plus $300 \mu \mathrm{M}$ GSH in hydroponic medium for $48 \mathrm{~h}$. Enzyme activities were assayed as described in Materials and methods. ${ }^{a}$ One unit of GS forms $1 \mu \mathrm{mol}$ of $\gamma$-glutamyl hydroxamate per min under the assay conditions. ${ }^{\mathrm{b}}$ One unit of GOGAT oxidizes $1 \mu \mathrm{mol}$ of NADH per min under the assay conditions. Data are the means \pm S.E.M. of three different experiments with five replicated measurements. Each value represents $n=15$. *Significant differences $P<0.05$, **Significant differences $P<0.01$ according to Tukey's multiple range test 
(a)

a)
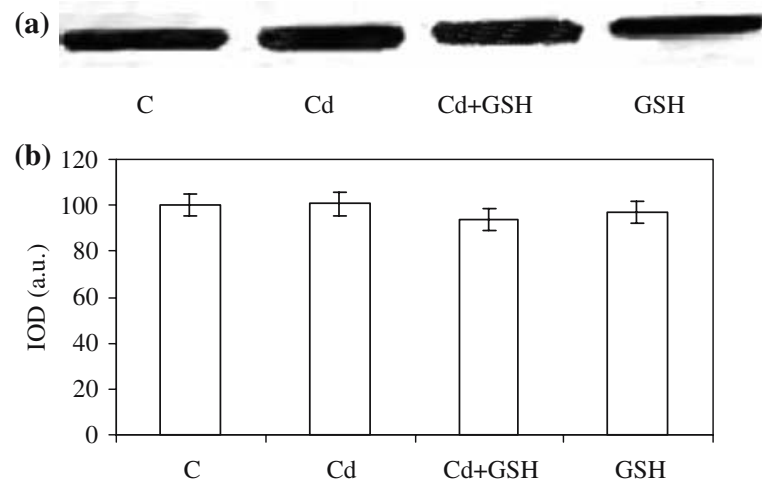

Fig. 1 Effect of cadmium and GSH treatments on GS protein abundance in soybean nodules. Soybean (Glycine max L.) nodulated plants were treated with nutrient solution devoid of cadmium and glutathione (control), or containing $200 \mu \mathrm{M}$ $\mathrm{CdCl}_{2}, 300 \mu \mathrm{M} \mathrm{GSH}$ or $200 \mu \mathrm{M} \mathrm{CdCl}_{2}$ plus $300 \mu \mathrm{M} \mathrm{GSH}$ in hydroponic medium for $48 \mathrm{~h}$. Proteins ( $40 \mu \mathrm{g}$ per well) were separated by native-PAGE. (a) Western blot analysis of GS protein expression. (b) Densitometry was done to quantify GS protein expression, and expressed as arbitrary units (a.u.) based on absolute integrated optical density (IOD). The blot is representative of 3 blots with a total of 4-5 samples/group between the 3 blots

(a)

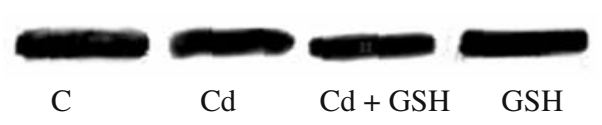

(b)

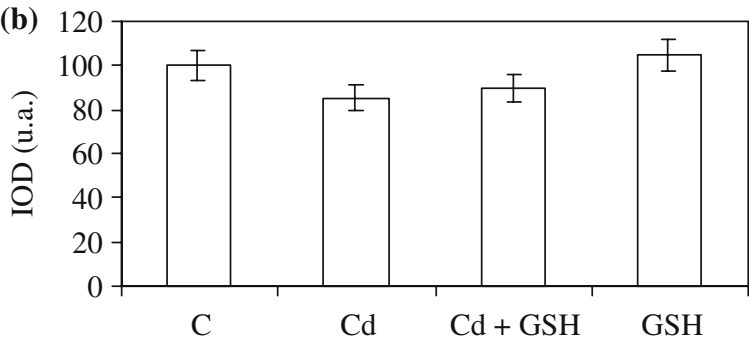

Fig. 2 Effect of cadmium and GSH treatments on GOGAT protein abundance in soybean nodules. Soybean (Glycine max L.) nodulated plants were treated with nutrient solution devoid of cadmium and glutathione (control), or containing $200 \mu \mathrm{M}$ $\mathrm{CdCl}_{2}, 300 \mu \mathrm{M} \mathrm{GSH}$ or $200 \mu \mathrm{M} \mathrm{CdCl}_{2}$ plus $300 \mu \mathrm{M} \mathrm{GSH}$ in hydroponic medium for $48 \mathrm{~h}$. Proteins (40 $\mu \mathrm{g}$ protein per well) were separated by native-PAGE. (a) Western blot analysis of GOGAT protein expression. (b) Densitometry was done to quantify GOGAT protein expression, and expressed as arbitrary units (a.u.) based on absolute integrated optical density (IOD). The blot is representative of 3 blots with a total of 4-5 samples/group between the 3 blots

residues was performed, the densitometric scanning was in agreement with the result obtained by spectrophotometric methods. Qualitative pattern of carbonylated proteins showed that $\mathrm{Cd}^{2+}$ ions increased oxidation of proteins with molecular weight higher than $66 \mathrm{kDa}$ (Fig. 4b).

GS and GOGAT protein oxidation

Taking into account the present results, the degree of GS and GOGAT oxidation was estimated. A significant oxidation of both proteins was observed (Fig. 5). This oxidation was completely prevented by GSH addition in the plant nutrient solution containing $\mathrm{Cd}^{2+}$.

\section{Discussion}

Glutamine and glutamate synthetase are key enzymes in nitrogen metabolism of higher plants. GS and GOGAT form the GS/GOGAT cycle, considered the main pathway for the primary assimilation of ammonium (Lea and Miflin 2004; Suzuki and Knaff 2005). The present investigation reveals that during exposure to $\mathrm{Cd}^{2+}$, GS and GOGAT activity levels were significantly diminished in soybean nodules. A decrease in these enzyme activities was observed in other species, such as maize (Boussama et al. 1999; Astolfi et al. 2004), pea (Chugh et al. 1992), bean (Gouia et al. 2000) and rice (Kumar and Dubey 1999; Chien et al. 2002), and reflects a general inhibition of primary nitrogen assimilation and even of the overall metabolic activity of the cell, because GS and GOGAT are also involved in recycling ammonium produced by photorespiration. But the mechanism of $\mathrm{Cd}^{2+}$ toxicity remained still unclear and no information about nodule response was available.

Cadmium is a powerful enzyme inhibitor (Das et al. 1997) and it has been demonstrated that it causes oxidative stress in plants (Benavides et al. 2005). Our previous results showed that $\mathrm{Cd}^{2+}$ produces oxidative stress and deleterious effects on the antioxidant defense system in soybean nodules (Balestrasse et al. 2001). In nodules exposed to $\mathrm{Cd}^{2+}$, GS and GOGAT activities decreased, however neither decrease in the protein abundance nor fragmentation was observed. Although no loss of band staining in both enzymes in SDS-PAGE was found, GS and GOGAT protein oxidation were produced. Previous studies (Levine et al. 1981) suggested that 


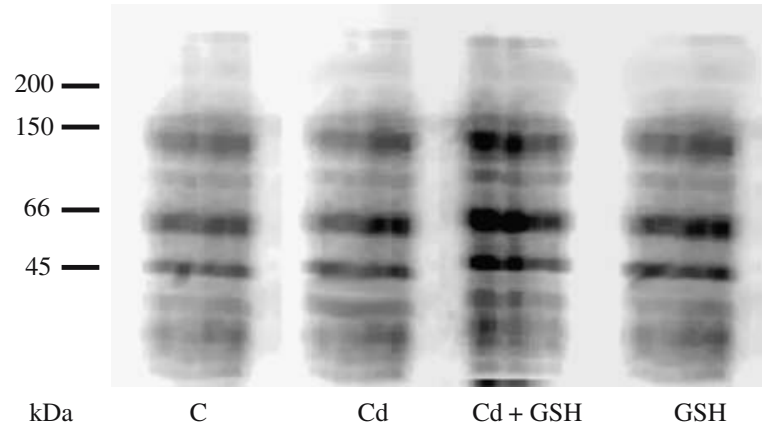

Fig. 3 Effect of cadmium and GSH treatments on total proteins in soybean nodules. Soybean (Glycine max L.) nodulated plants were treated with nutrient solution devoid of cadmium and glutathione (control), or containing $200 \mu \mathrm{M}$ $\mathrm{CdCl}_{2}, 300 \mu \mathrm{M} \mathrm{GSH}$ or $200 \mu \mathrm{M} \mathrm{CdCl}_{2}$ plus $300 \mu \mathrm{M} \mathrm{GSH}$ in hydroponic medium for $48 \mathrm{~h}$. Proteins $(50 \mu \mathrm{g})$ were subjected to SDS-PAGE (12\% w/v polyacrylamide) and stained with Coomassie Brilliant Blue R-250. The electrophoresis data shown are representative of two independent experiments with three replicates

the turnover of GS from E. coli occur in two steps. Oxidative modification of GS was implicated as the first step in the turnover of this enzyme in bacteria. Glutamine synthetase is oxidized, resulting in inactivation, loss of at least one histidine, and the generation of one or more carbonyl groups. In the second step, oxidized GS is degraded by specific proteases (Levine 1983; Rivett and Levine 1990). In the chloroplast, the stromal GS appears to be highly labile to ROS attack, because GS degradation in illuminated chloroplasts requires the function of the photosynthetic electron transport chain (Stieger and Feller 1997). Chloroplastic GS of wheat seedlings has been reported to be particularly prone to degradation under oxidative stress conditions (Palatnik et al. 1999). Moreover, by incubating of soybean root extracts enriched in GS, in a metal-catalyzed oxidation system to produce the hydroxyl radical, Ortega et al. (1999) have shown that GS was oxidized. Reactive oxygen species react with proteins and generate oxidation products such as carbonyl groups on the molecule (Chao et al. 1997). In barley leaves (Hordeum vulgare L.), GS decreased and GOGAT was absent under a high $\mathrm{Cu}$ concentration. The development of toxicity symptoms corresponded to an accumulation of $\mathrm{Cu}$ in the leaves and to a gradual increase in protein carbonylation (Demirevska-Kepova et al. 2004). Although $\mathrm{Cd}^{2+}$ is a redox inactive metal, it caused accumulation of oxidatively damaged proteins in
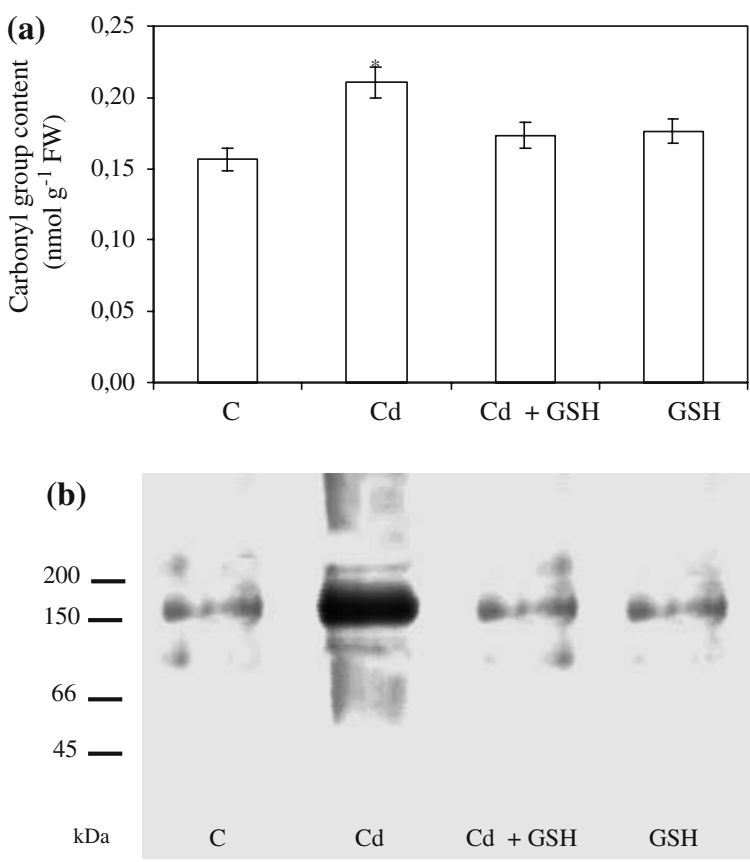

Fig. 4 Effect of cadmium and GSH treatments on proteins oxidation. Soybean (Glycine max L.) nodulated plants were treated with nutrient solution devoid of cadmium and glutathione (control), or containing $200 \mu \mathrm{M} \mathrm{CdCl}_{2}, 300 \mu \mathrm{M}$ GSH or $200 \mu \mathrm{M} \mathrm{CdCl} 2$ plus $300 \mu \mathrm{M}$ GSH in hydroponic medium for $48 \mathrm{~h}$. (a) Total carbonyl groups content. Values are means \pm s.e $(n=15)$. * Significant differences $P<0.05$ according Tukeýs multiple range test. (b) The DNPH-derivatized proteins (50 $\mu \mathrm{g}$ of total protein) were subjected to a SDS-PAGE $(12.5 \%$ w/v polyacrylamide). Western blotting was performed using anti-DNP antibody and bands were visualized by densitometry as described Material and methods. The positions of molecular mass markers (in $\mathrm{kDa}$ ) are shown on the left. The blot is representative of 3 blots with a total of 4-5 samples/group between the 3 blots

soybean nodules, as it was observed in other plant species such as pea plants (Romero-Puertas et al. 2002). Cadmium exposure resulted in oxidation of high molecular weight nodule proteins, which included GS and GOGAT. GS of bacteroids from root nodules of Glycine max is a large protein of about $\mathrm{Mr}$ 760,000 consisting of 12 apparently identical $\mathrm{Mr}$ 63,000 subunits (Bhandari and Nicholas 1986). GOGAT of higher plants and alfalfa nodules is a monomer of about $\mathrm{Mr}$ 200,000 (Anderson et al. 1989). Besides, Ortega et al. (1999) have reported a dramatic increase in the level of the oxidized forms of GS subunits, suggesting that the oxidative modification may be an intermediate step in the turnover of GS in vivo. This fact, could be explaining, at least in 


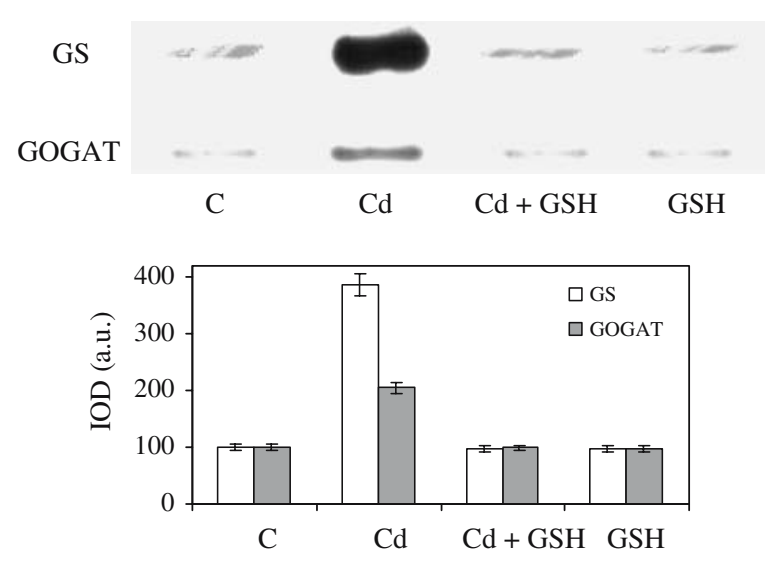

Fig. 5 Identification of GS and GOGAT oxidized proteins. Soybean (Glycine max L.) nodulated plants were treated with nutrient solution devoid of cadmium and glutathione (control), or containing $200 \mu \mathrm{M} \mathrm{CdCl}_{2}, 300 \mu \mathrm{M} \mathrm{GSH}$ or $200 \mu \mathrm{M} \mathrm{CdCl}_{2}$ plus $300 \mu \mathrm{M}$ GSH in hydroponic medium for $48 \mathrm{~h}$. Nodule extracts reacted with 2,4 DNPH and derivatized proteins were immunoseparated with antibody anti-DNP, the DNPH-derivatized proteins (50 $\mu \mathrm{g}$ of total protein) were subjected to SDSPAGE $(12.5 \% \mathrm{w} / \mathrm{v}$ polyacrylamide). Western blotting was performed using anti-GS and anti-GOGAT antibodies. Bands were visualized by densitometry as described in Material and methods. The blot is representative of 3 blots with a total of 4-5 samples/group between the 3 blots

part, our results, which demonstrated the higher susceptibility to oxidation of GS as compared to GOGAT.

Protein carbonylation is an irreversible oxidative process and it would be expected to contribute to inhibition or the impairment of multiple enzymes, thus affecting cellular functions ranging from protein synthesis, energy production and cytoskeleton dynamics to signal transduction (Sohal 2002; Sohal et al. 2002). In the present study, the antioxidant glutathione protected the nodule against the deleterious effect of the metal. Reduced glutathione is the predominant non-protein thiol, redox-buffer, phytochelatin precursor and substrate for keeping the ascorbate in reduced form in the ascorbate-glutathione pathway (Gratäo et al., 2005). Addition of GSH avoided accumulation of carbonylated proteins and hence prevented the oxidation of GS and GOGAT protein by $\mathrm{Cd}^{2+}$ treatment.

The protective effect of external GSH supply is apparently not due to interference with $\mathrm{Cd}$ uptake into the nodules. Therefore, it is likely that it is attributable to an elevated cellular GSH content in the nodules, due to uptake from the nutrient solu- tion. Elevated cellular levels of GSH, which is the low-affinity substrate for phytochelatin synthase (Vatamaniuk et al. 2000), have been shown to enhance phytochelatin-based $\mathrm{Cd}$ sequestration and tolerance in Indian mustard and tobacco (Zhu et al. 1999; Pomponi et al. 2006). Alternatively, the enzyme protection might also directly result from the antioxidant activity of GSH as such, at least in part.

Although increments in protein carbonyl groups content and the inactivation of the nitrogen assimilation process in plants exposed to $\mathrm{Cd}^{2+}$ was previously described, there is no information about the possible mechanisms involved. The present study demonstrates that the decrease in activities of both enzymes of the nitrogen assimilation pathway, GS and GOGAT, was due to an oxidation of the proteins, more than a modification of the protein expression. In addition, these findings reinforce the notion that glutathione is a very important antioxidant in nodules, preventing the oxidation of proteins and protecting the nitrogen assimilation pathway.

Acknowledgements We are very grateful to Dr. A.J. Márquez Cabeza, Departamento de Bioquímica Vegetal y Biología Molecular, Universidad de Sevilla, España for providing the rabbit antibodies against GOGAT and GS. This work was supported by grants from the Universidad de Buenos Aires (Argentina) and from Consejo Nacional de Investigaciones Científicas y Técnicas (CONICET) (Argentina). K.B.B., S.M.G. and M.L.T. are career investigators from CONICET.

\section{References}

Anderson MP, Vance CP, Heichel GH, Miller SS (1989) Purification and characterization of NADH-glutamate synthase from alfalfa root nodules. Plant Physiol 90:351-358

Astolfi S, Zuchi S, Passera C (2004) Role of sulphur availability on cadmium-induced changes of nitrogen and sulphur metabolism in maize (Zea mays L.) leaves. J Plant Physiol 161:795-802

Balestrasse KB, Benavides MP, Gallego SM, Tomaro ML (2003) Effect of cadmium stress on nitrogen metabolism in nodules and roots of soybean plants. Funct Plant Biol 30:57-64

Balestrasse KB, Gallego SM, Tomaro ML (2004) Cadmiuminduced senescence in nodules of soybean (Glycine max L.) plants. Plant Soil 262:373-381

Balestrasse KB, Gallego SM, Benavides MP, Tomaro ML (2005) Polyamines and proline are affected by cadmium stress in nodules and roots of soybean plants. Plant Soil 270:343-353

Balestrasse KB, Gardey L, Gallego SM, Tomaro ML (2001) Response of antioxidant defence system in soybean nodules and roots subjected to cadmium stress. Aust J Plant Physiol 28:497-504 
Benavides MP, Gallego SM, Tomaro ML (2005) Cadmium toxicity in plants. Braz J Plant Physiol 17:21-34

Berlett BS, Stadtman ER (1997) Protein oxidation in aging, disease and oxidative stress. J Biol Chem 272:20313-20316

Bhandari B, Nicholas DJD (1986) Properties of glutamine synthetase of bacteroids from root nodules of Glycine max. Plant Sci 44:89-96

Boussama N, Ouariti O, Suzuki A, Ghorbal MH (1999) Cd-stress on nitrogen assimilation. J Plant Physiol 155:310-317

Bradford MM (1976) A rapid and sensitive method for the quantitation of microgram quantities of protein utilizing the principle of protein-dye binding. Anal Biochem 72:248-254

Chao CC, Ma YS, Stadtman ER (1997) Modification of protein surface hydrophobicity and methionine oxidation by oxidative system. Proc Natl Acad Sci USA 94:2969-2974

Chien HS, Lin CC, Wang JW, Chen CT, Kao CH (2002) Changes in ammonium ion content and glutamine synthetase activity in rice leaves caused by excess cadmium are a consequence of oxidative damage. Plant Growth Reg 36:41-47

Chugh LK, Gupta VK, Sawhney SK (1992) Effect of cadmium on enzymes of nitrogen metabolism in pea seedlings. Phytochemistry 31:395-400

Cullimore JV, Miflin BJ (1984) Immunological studies on glutamine synthetase using antisera raised to the two plants forms of the enzyme from $P$. vulgaris root nodules. J Exp Bot 35:581-587

Das P, Samantaray S, Rout GR (1997) Studies on cadmium toxicity in plants: a review. Environ Pollut 98:29-36

Demirevska-Kepova K, Simova-Stoilova L, Stoyanova Z, Hölzer R, Feller U (2004) Biochemical changes in barley plants after excessive supply of copper and manganese. Environ Exp Bot 52:253-266

Gallego SM, Kogan MJ, Azpilicueta CE, Peña C, Tomaro ML (2005) Glutathione-mediated antioxidative mechanisms in sunflower (Helianthus annuus L.) cells in response to cadmium stress. Plant Growth Regul 46:267-276

Gouia H, Ghorbal MH, Meyer C (2000) Effects of cadmium on activity of nitrate reductase and on other enzymes of the nitrate assimilation pathway in bean. Plant Physiol Biochem 38:629-638

Gratäo PL, Polle A, Lea PJ, Azevedo RA (2005) Making the life of heavy metals-stressed plant a little easier. Funct Plant Biol 32:481-494

Groat RG, Vance CP (1981) Root nodule enzymes of ammonia assimilation in alfalfa (Medicago sativa L.). Plant Physiol 67:1198-1203

Hoagland DR, Arnon DI (1957) The water culture method for growing plants without soil. Agricultural Experimental Station of the University of California. Berkeley Circular 347. University of California, Berkeley

Kanamori T, Matsumoto H (1972) Glutamine synthetase from rice plant roots. Arch Biochem Biophys 125:400-412

Kumar RG, Dubey RS (1999) Glutamine synthetase isoforms from rice seedlings: effects of stress on enzyme activity and the protective roles of osmolytes. J Plant Physiol 155:118-121

Laemmli UK (1970) Cleavage of structural proteins during the assembly of the head of bacteriophage T4. Nature 227:680-685
Lancien M, Gadal P, Hodges M (2000) Enzyme redundancy and the importance of 2-oxoglutarate in higher plant ammonium assimilation. Plant Physiol 123:817-824

Lea PJ, Miflin BJ (2004) Glutamate synthase and the synthesis of glutamate in plants. Plant Physiol Biochem 41:555-564

Levine RL (1983) Oxidative modification of glutamine synthetase. J Biol Chem 258:11823-11827

Levine RL, Garland D, Oliver CN, Amici A, Climent I, Lenz A, Ahn B, Shaltiel S, Stadman ER (1990) Determination of carbonyl content in oxidatively modified proteins. Meth Enzymol 106:464-478

Levine RL, Oliver CN, Fulks RM, Stadtman ER (1981) Turnover of bacterial glutamine synthetase: oxidative inactivation precedes proteolysis. Proc Natl Acad Sci USA 78:2120-2124

May MJ, Vernoux T, Leaver C, Van Montagu M, Inze D (1998) Glutathione homeostasis in plants: implications for environmental sensing and plant development. J Exp Bot 49:649-667

Nyström T (2005) Role of oxidative carbonylation in protein quality control and senescence. EMBO J 24:1311-1317

Ortega JL, Roche D, Sengupta-Gopalan A (1999) Oxidative turnover of soybean root glutamine synthetase. In vitro and in vivo studies. Plant Physiol 119:1483-1495

Palatnik JF, Carrillo N, Valle EM (1999) The role of photosynthetic electron transport in the oxidative degradation of chloroplastic glutamine synthetase. Plant Physiol 121:471-478

Pomponi M, Censi V, Di Girolamo V, De Paolis A, Sanità di Toppi L, Aromolo R, Costantino P, Cardarelli M (2006) Overexpression of Arabidopsis phytochelatin synthase in tobacco plants enhances $\mathrm{Cd} 2+$ tolerance and accumulation but not translocation to the shoot. Planta 223:180-190

Rivett AJ, Levine RL (1990) Metal-catalyzed oxidation of Escherichia coli glutamine synthetase: correlation of structural and functional changes. Arch Biochem Biophys 278:26-34

Romero-Puertas MC, Palma JM, Gómez M, Del Río LA, Sandalio LM (2002) Cadmium causes the oxidative modification of proteins in pea plants. Plant Cell Environ 25:677-686

Sohal RS (2002) Role of oxidative stress and protein oxidation in the aging process. Free Rad Biol Med 33:37-44

Sohal RS, Mockett RJ, Orr WC (2002) Mechanisms of aging: an appraisal of the oxidative stress hypothesis. Free Rad Biol Med 33:575-586

Stieger A, Feller U (1997) Requirement for the light-stimulated degradation of stromal proteins in isolated pea (Pisum sativum L.) chloroplasts. J Exp Bot 48:1639-1645

Suzuki A, Knaff DB (2005) Glutamate synthetase: structural, mechanistic and regulatory properties, and role in the amino acids metabolism. Photosynth Res 83:191-217

Vatamaniuk OK, Mari S, Lu YP, Rea PA (2000) Mechanism of heavy metal ion activation of phytochelatin (PC) synthase: blocked thiols are sufficient for PC synthase-catalyzed transpeptidation of glutathione and related thiol peptides. J Biol Chem 275:31451-31459

Zhu YL, Pilon-Smits EAH, Tarun AS, Weber SU, Juoanin L, Terry N (1999) Cadmium tolerance and accumulation in Indian mustard is enhanced by overexpressing gammaglutamylcysteine synthetase. Plant Physiol 121:1169-1177 